\title{
Journal of Pharmaceutical Research
}

\section{ORIGINAL ARTICLE}

\section{Phytochemical Evaluation of Ficus Carica Seeds and their Cold Pressed Oil}

\author{
Zeliha Ustun-Argon ${ }^{1,2, *}$, Zeliha Sari ${ }^{3,4}$, Ali Gokyer ${ }^{3,4}$, Sidika Buyukhelvacigil-Ozturk ${ }^{3,4}$ \\ ${ }^{1}$ Department of Biosystem Engineering, Eregli Faculty of Agriculture, Necmettin Erbakan University, Konya, Turkey \\ ${ }^{2}$ Medical and Cosmetic Plants Application and Research Center, Necmettin Erbakan University, Konya, Turkey \\ ${ }^{3}$ Zade \& Zade Vital İbni Sina R\&D Center, Konya, Turkey \\ ${ }^{4}$ DUAMER Natural Products Research and Development Center, Konya, Turkey
}

\section{ARTICLE INFO}

Article history:

Received 25.09.2021

Revised 21.12.2021

Accepted 27.12.2021

Published 29.12.2021

* Corresponding author.

Zeliha Ustun-Argon

ustun.zeliha@gmail.com

zargon@erbakan.edu.tr

https://doi.org/

$10.18579 /$ jopcr/v20i4.2

\begin{abstract}
A B S T R A C T
The use of plant materials as the source of oil and functional foods is becoming more important with the new trends and scientific research. In this study, fig (Ficus carica) seed, which is a rarely found, seed and its oil, have been studied to determine the phytochemical properties for possible applications. Fig seeds were obtained from Aydın, Turkey. The oil was extracted by the cold press method. The seeds were analyzed for oil yield, protein, ash, ash insoluble in hydrochloric acid and trace elements. The oil was evaluated for fatty acid, sterol compositions by GC and the volatiles were analyzed with GCMS, tocopherols analyzed by HPLC, total phenolic content and antioxidant activity were determined spectrophotometrically. The oil was also evaluated for free fatty acid (FFA), refractive index (RI), peroxide (PV) and p-anisidine value. The results showed that $F$. carica has $22.7 \%$ oil yield and was characterized by linolenic $(41.27 \%)$, linoleic $(30.06 \%)$, and oleic acids (18.10\%). Total phenolics were $79.5 \mathrm{mgGAE} / 100 \mathrm{~g}$, and nine different sterol components were analyzed and $\beta$-sitosterol was at the highest rate. The $\alpha-\beta-\gamma-\delta$ tocopherol content was $6.088,0.18,634$, $18 \mathrm{mgkg}^{-1}$, respectively. Antioxidant capacity was $52.54 \%$. Fenchone, cymene, styrene d-limonene, linalool, camphor were found as important volatiles. Quality parameters were FFA (\% oleic acid) 0.90 , RI $\left(40^{\circ} \mathrm{C}\right)$ 1.4721, $\mathrm{PV}$ (meq $\mathrm{O}_{2} / \mathrm{kg}$ oil) 2.2, p-anisidine 2.22. As a result, F. carica oil can be an alternative oil source and a good option for functional foods with their rich contentof phytochemicals. For the future, more studies need to be done for both the seeds and the oil for further applications.
\end{abstract}

Keywords: Ficus carica seed; cold pressed oil; fig seed; phytochemical properties

\section{INTRODUCTION}

Ficus spp. is one of the important plants which represents a source since ancient times for food and health. Its importance is remarkable enough as to be in religious sacred texts. ${ }^{1,2}$ Ficus (Moraceae) comprises one of the largest genera of angiosperms worldwide with more than 800 species of hemiepiphytes, trees, climbers, shrubs, creepers ${ }^{3}$ and these are grown in different parts of the world with subtropical climates, especially in Southwest Asia and the Mediterranean region. ${ }^{4,5}$

Figs are one of the fruits that have been studied the most. The fruit's primary and secondary metabolites, nutritional value and health benefits have been evaluated in detail and the data from traditional medicine have supported the significance of this plant. The researchers showed that consuming dried fig on a daily basis is believed to keep up body strength by supplying the daily requirement of vitamins in a natural way. ${ }^{2,6,7}$ Pharmacological reports stated that figs are used for many different purposes with a wide range of health benefits including antipyretic, antiinflammatory, antiplatelet, antihelmintic, hepatoprotective, hypoglycemic, hypocholestrolemic, anticancer, antituberculosis, and antioxidant effects. ${ }^{3,5,8-12}$ It also is used for insomnia, anxiety ${ }^{13}$, eye vision problems, and loss of appetite. ${ }^{1,14}$

Although fig plants have been subjected to various studies, most of the phytochemical and health studies have been issued on fruits, leaves, stems and roots of the fig. ${ }^{1,3,5,7}$ Only a few researches have been conducted on the fig seeds and their cold pressed oil. F. carica seeds and their cold pressed oil may be considered to be rarely found commercial products as the sustainability of the seeds is very low and 
cold pressed oil production is very limited. Therefore this study has focused on these less studied parts of the fig plant to evaluate the possibility of alternative usages of the fruit for value-added products from which the fruit and oil manufacturers and the related industries may benefit. ${ }^{15}$

In this study, Ficus carica seeds from Aydin, Turkey and their cold pressed oil are evaluated for their phytochemical and physicochemical properties. To be able to reveal the dietary importance of fig seed oil, the cold press method is preferred for oil extraction. Cold press method is recommended for the minor oils, since no organic solvent or heat treatment were used during the process, phytochemical and sensory properties of oil, and beneficial components for health are protected. ${ }^{16-18}$ The fig seeds have been analyzed for oil yield, trace elements, protein, total ash and ash insoluble in hydrochloric acid. The fatty acid and sterol compositions, total phenolics, tocopherol compositions, antioxidant capacity, and volatile components of the oil are determined. The cold pressed oil also was evaluated for free fatty acid content, refractive index, peroxide and $\mathrm{p}$-anisidine value. To the best of our knowledge, this is the most extensive study about the fig seeds and their oils including volatile components.

\section{MATERIAL AND METHODS}

\section{Seeds and oil samples}

Seed samples were supplied from local orchards in the Aydın Region. The Sarilop variety of the figs was dried naturally, and their seeds were separated from the flesh and other impurities in its place by the grower. Seeds are extracted by using the cold press method. The oil extraction process was completed at Zade Vital Pharmaceuticals Inc. under GMP conditions. The process temperature was lower than 40 degrees Celsius and no heating application or any chemicals were used.

\section{Chemicals}

Chemicals were analytical or chromatographic grade, with trademarks J.T. Baker and Sigma-Aldrich. For all analysis Millipore ultrapure water (Type I) was used.

\section{Protein, Total Ash, Ash Insoluble in Hydrochloric Acid}

Total protein content was determined by using the Kjeldahl method. Protein content was calculated with the general factor (6.25). ${ }^{19}$ Total ash analysis was completed according to EP 8.0 method $2.4 .16^{20}$ and for ash insoluble in hydrochloric acid analysis EP 8.0 method 2.8.1. ${ }^{21}$

\section{Trace elements}

Trace elements analysis was conducted by ICP-OES using standard methods. ${ }^{22}$ According to the method $0.5 \mathrm{~g}$ fig seed was weighed and $7 \mathrm{~mL} \mathrm{HNO}_{3} 65 \%$ and $1 \mathrm{~mL} \mathrm{H}_{2} \mathrm{O}_{2}$
$30 \%$ was added. A microwave oven (Milestone Ethos One) was used for digestion of samples. The microwave digestion application was done with parameters which are shown in Table 1. The sample was cooled down for a period of time until the samples temperature reached $25^{\circ} \mathrm{C}$. After dilution to $200 \mathrm{~mL}$, the sample was analyzed by ICP-OES (Shimadzu ICPE-9000).

Table 1: Microwave program for digestion of samples

\begin{tabular}{llllll}
\hline Step & Time & T1 & T2 & $\mathbf{P}$ & Power \\
\hline 1 & $00: 15: 00$ & $200{ }^{0} \mathrm{C}$ & $110{ }^{0} \mathrm{C}$ & 45 bars & Max power \\
2 & $00: 15: 00$ & $200{ }^{0} \mathrm{C}$ & $110{ }^{0} \mathrm{C}$ & 45 bars & Max power \\
\hline
\end{tabular}

\section{Fatty acid methyl esters (FAME) analysis, Sterol Composition}

A fatty acid methyl esters (FAME) analysis was conducted according to COI/T.20/Doc. No 33 for olive oils method. ${ }^{23}$ $70 \mathrm{mg}$ sample of oil was used for the analysis. Fatty acids were identified by retention time. The standard A 37 component mixture of FAME (Supelco) was used for determination of retention time. The area ratio, which is under the relevant peak, was used for the quantitative analysis. The calculation has been completed by using area normalization procedure. As an instrument the Shimadzu 2010 Plus GC-FID system was used. The column chosen was a Restek Rt 2560 capillary column $(100 \mathrm{~m} \times 0.25 \mathrm{~mm}$ ID $\times 0.2 \mu \mathrm{m})$. The injection and detector temperatures were set at $250^{\circ} \mathrm{C}$ and $260^{\circ} \mathrm{C}$, respectively. The temperature program was as follows; the oven temperature was held at $140^{\circ} \mathrm{C}$ for $1 \mathrm{~min}$ and then increased to $240^{\circ} \mathrm{C}$ at a rate of $4^{\circ} \mathrm{C} / \mathrm{min}$ and held for $5 \mathrm{~min}$. The split ratio was at 1:100. Sterol analysis was completed according to EP 8.0 2.4.23 sterols in fatty oil with the Shimadzu GC-2010 Plus. ${ }^{24}$

\section{Phenolic Extraction}

Phenolic extraction has been conducted according to the method given by Ferhat et al. ${ }^{25}$ The methanol extract has been prepared by weighing $1 \mathrm{~g}$ of fig seed oil into a centrifuge tube and adding $1 \mathrm{~mL}$ of methanol/water $(80 / 20, \mathrm{v} / \mathrm{v})$ into the tube. After stirring the mixture in a vortex apparatus (10 $\mathrm{min})$, the tube was centrifuged $(3800 \mathrm{rpm}, 15 \mathrm{~min}$ ) to separate the methanol layer. The extraction has been done twice.

\section{Determination of total phenolic content (TPC)}

Total phenolic content of the methanol extracts was determined by using the method given in the literature by Ferhat et al. ${ }^{25}$ For determination of total phenolic content, $0.5 \mathrm{ml}$ of methanolic extract solution, $5 \mathrm{ml}$ distilled water and $1 \mathrm{~mL}$ Folin-Ciocalteu reagent were added to the test tube respectively and the tube was shaken. After 4 minutes, $0.8 \mathrm{ml}$ of $\mathrm{Na}_{2} \mathrm{CO}_{3}(7.5 \%)$ solution was added into the tube. 
The mixture was left for $2 \mathrm{~h}$ with intermittent shaking. Absorbance of the mixture was measured at $640 \mathrm{~nm}$. Each assay was carried out in triplicate.

The following equation which was obtained from the standard gallic acid graph is used to calculate the concentrations of phenolic compounds:

Absorbance $=0.006$ gallic acid $(\mathrm{mg})-0.021(\mathrm{R} 2=0.969)$

\section{Tocopherol Content}

For tocopherol analysis the method described by Celenk et $\mathrm{al}^{26}$ was used. The column chosen was Lichrosorb Si 60, 250 $\mathrm{x} 4.0 \mathrm{~mm}$ for the HPLC analysis. The analysis was completed by using hexane/2-propanol $(99,5 / 0,5)(\mathrm{v} / \mathrm{v})$ as mobile phase, injection volume was $20 \mu \mathrm{L}$ at $25 \pm 1{ }^{\circ} \mathrm{C}$, the flow rate was $0,8 \mathrm{~mL} / \mathrm{min}$. All the injections were triplicate for each of the concentrations of tocopherols. The Tocopherol Set (Merck) was used as a standard which includes a four-vial pack containing $\alpha, \beta, \gamma$, and $\delta$-tocopherols. The data of peak areas are used for calibration graphs. The data from corresponding concentrations, the excitation at $290 \mathrm{~nm}$ wavelengths and the emission at $330 \mathrm{~nm}$ were used for calculation of the linear regression equations.

\section{DPPH free radical-scavenging assay}

The free radical scavenging activity was determined by the DPPH assay spectrophotometrically. ${ }^{25}$ According to the method, $1.95 \mathrm{ml}$ of DPPH $(0.025 \mathrm{mg} / \mathrm{ml})$ prepared in anhydrous methanol was added into $50 \mu \mathrm{l}$ of sample methanolic solution. The absorbance was measured thirty minutes later, at $515 \mathrm{~nm}$. In the results, higher free radical scavenging activity was found related to lower absorbance of the reaction mixture. The following equation is used to calculate the capability of scavenging the DPPH radical:

$D P P H$ radical scavenging effect $(\%)=$ $\frac{\text { A control-A sample }}{\text { A control }} \times 100$

With respect to the terms of the formula above, "A control" is defined here as the first concentration of the DPPH and "A ${ }_{\text {sample" }}$ is defined here as the absorbance of the remaining concentration of DPPH with the extract.

\section{Volatile oils}

Volatile compounds were identified by using the gas chromatography technique coupled with mass spectrometry (GC-MS). The instrument employed was a Shimadzu GCMS with mass selective detector which is the QP 2010 plus model. The chromatographic column was Restek Rxi-5ms, thickness was $0.25 \mu \mathrm{m}$, length was $30 \mathrm{~m}$, and the internal diameter was $0.25 \mathrm{~mm}$. The used oil sample amount was not less than $1 \mathrm{~mL}$, and the compounds were identified by comparing the database library of the GC with the mass spectra obtained. The amounts of volatile components were determined by the analysis instrument, using the area of each peak for integration and calculation results were given as percentages. Chromatographic conditions were set as column oven temperature to $40^{\circ} \mathrm{C}$, injection temperature to $250{ }^{\circ} \mathrm{C}$, injection mode was split, total flow was 40,8 $\mathrm{mL} / \mathrm{min}$, column flow was $1,80 \mathrm{~mL} / \mathrm{min}$ and split ratio was 20. The oven temperature program was as follows: the oven temperature was held at $40^{\circ} \mathrm{C}$ for $3 \mathrm{~min}$. It was then increased to $240^{\circ} \mathrm{C}$ at a rate of $4^{\circ} \mathrm{C} / \mathrm{min}$ and held stationary for $5 \mathrm{~min} .{ }^{27}$

\section{Free fatty acids (FFA), peroxide value (PV), refractive index (RI) and p-anisidine Value}

The free fatty acid (FFA) content was analyzed according to EP 8.0 method $2.5 .1^{28}$, and the peroxide value (PV) was calculated with EP 8.0 method 2.5.5. ${ }^{29}$ The refractive index was determined by using EP 8.0 method 2.2.6 $6^{30}$ and Rudolph J57WR, and for p-Anisidine value A.O.C.S Official Method Cd 18-90 was used. ${ }^{31}$ The $\mathrm{p}$-Anisidine values were calculated using the following equation: $\mathrm{p}-\mathrm{A} . \mathrm{V} .=25^{\star}(1,2 \mathrm{As}-\mathrm{Ab}) / \mathrm{m} .{ }^{32}$

\section{RESULTS}

\section{Oil content, Protein, Ash, Ash Insoluble in Hydrochloric Acid, Trace Elements of the Fig Seeds}

F. carica seeds have been evaluated for their cold pressed oil content, protein, ash, ash insoluble in hydrochloric acid, potassium, calcium, sodium, magnesium and iron. The oil yield of fig seed with the cold press method was found at $22.7 \%$. Protein, ash and ash insoluble in hydrochloric acid values were found in our study as $14.65 \%, 2.6 \mathrm{~g}$ and $0.2 \mathrm{~g}$, respectively. Potassium, magnesium and calcium were the main trace elements in the dried fig seeds (Table 2).

\begin{tabular}{ll}
\multicolumn{2}{l}{ Table 2: Trace Elements of Fig Seeds } \\
\hline Element & Amount $(\mathbf{m g} / \mathbf{1 0 0} \mathbf{g})$ \\
\hline Potassium & 430.0 \\
Magnesium & 227.9 \\
Calcium & 98.28 \\
Sodium & 39.3 \\
Iron & 10.6 \\
\hline
\end{tabular}

\section{Fatty acid methyl esters (FAME) composition}

Fig seed oil fatty acid methyl esters (FAME) composition are found most abundantly in polyunsaturated fatty acids (PUFA) and monounsaturated fatty acid (MUFA) with $41.27 \%$ alpha linolenic acid, $30.06 \%$ linoleic acid and $18.10 \%$ oleic acid (Table 3$).^{33}$

\section{Total phenolic content, s terols}

Total phenolic content of the cold pressed fig seed oil was found to be $79.5 \mathrm{mgGAE} / 100 \mathrm{~g}$ in our study and sterol analysis showed that beta-sitosterol was the most abundant components and total sterol was $6519.40 \mathrm{mg} \mathrm{kg}-1$ (Table 4). 
Table 3: Fatty Acid Methyl Ester Composition of Fig Seeds Oil

\begin{tabular}{ll}
\hline Fatty Acid & $\%$ \\
\hline Palmitic acid C16:0 & 6.81 \\
Palmitoleic acid C16:1 & 0.06 \\
Margaric acid C 17:0 & 0.06 \\
Stearic acid C18:0 & 2.82 \\
Oleic acid C18:1 (n-9) & 18.10 \\
Linoleic acid C18:2 (n-6) & 30.06 \\
Gamma linolenic acid C18:3 (n-6) & 0.18 \\
Alpha linolenic acid C18:3 (n-3) & 41.27 \\
Arachidicacid C20:0 & 0.19 \\
Eicosenoic acid C20:1 (n-9) & 0.26 \\
Eicosadienoic acid C20:2 & 0.03 \\
Behenic acid C22:0 & 0.08 \\
Lignoceric acid C24:0 & 0.03 \\
MUFA & 18.42 \\
PUFA & 71.54 \\
TSFA & 9.99 \\
TUFA & 89.96 \\
MUFA/PUFA & 0.25 \\
TSFA/TUFA & 0.11 \\
$\omega-6 / \omega$-3 (18:2/18:3) & 0.72 \\
\hline MUFA Moun
\end{tabular}

MUFA: Monounsaturated fatty acids; PUFA: Polyunsaturated fatty acids; TSFA: Total saturated fatty acids; TUFA: Total unsaturated fatty acids

Table 4: Sterol Composition of Fig Seeds Oil

\begin{tabular}{ll}
\hline Sterol & \% \\
\hline Beta-sitosterol & 64.45 \\
Delta-5-avenasterol & 19.55 \\
Delta-7-avenasterol & 4.91 \\
Cholestanol & 2.97 \\
Campesterol & 2.90 \\
Stigmasterol & 2.11 \\
Delta-7-stigmasterol & 1.24 \\
Sitositanol & 1.15 \\
Clerosterol & 0.66 \\
Total sterol & $651.94{\mathrm{mg} 100 \mathrm{~g}^{-1}}$
\end{tabular}

\section{Tocopherol content and a ntioxidant capacity}

F. carica seeds oil have been analyzed for their tocopherol content and in the results $\alpha, \beta, \gamma, \delta$-tocopherol were detected. The results were for $\alpha$-tocopherol $6.088 \mathrm{mg} \mathrm{kg}^{-1}$, $\beta$-tocopherol $0.18 \mathrm{mg} \mathrm{kg}^{-1}, \gamma$-tocopherol $634 \mathrm{mg} \mathrm{kg}^{-1}, \delta$ tocopherol $18 \mathrm{mg} \mathrm{kg}^{-1}$ and total tocopherol was 658.27 $\mathrm{mg} \mathrm{kg}{ }^{-1} \cdot \gamma$-tocopherol has the most abundant content exceptionally while $\beta$-tocopherol has the lowest range. According to the free radical scavenging activity (DPPH) analysis the antioxidant capacity of the oil was determined at $52.54 \%$.

\section{Volatile oils}

Ninety-fourdifferent components are determined in the Cold pressed oil of F. carica seeds and major volatiles are shown in Table 5.

\section{Free fatty acid, peroxide value, refractive index and p-anisidine}

Physicochemical properties of fig seed cold pressed oil found for free fatty acid (FFA), the peroxide value (PV), the refractive index $(\mathrm{RI})\left(40{ }^{\circ} \mathrm{C}\right)$ and $\mathrm{p}$-anisidine were $0,90 \%$ oleic acid, 2.2 meq $\mathrm{O}_{2} / \mathrm{kg}$ oil, 1.4721 and 2.22 respectively. Peroxide value, free fatty acid and p-anisine levels were within the acceptance levels for edible oils

Table 5: Major Volatile Components of Fig Seed Oil

\begin{tabular}{ll}
\hline Volatile Oils & Amount (\%) \\
\hline Isobutyl acetate & 4.49 \\
1-Propanol, 2,2-dimethyl-, acetate & 2.41 \\
Hexanal & 2.50 \\
2-furancarboxaldehyde & 1.51 \\
1-Butanol 3-methyl acetate & 17.02 \\
Butanoic acid, 3-methyl & 1.23 \\
Styrene & 18.57 \\
Butanoic acid, 3-methyl, ethyl ester, & 1.10 \\
1-Butanol 2-methyl acetate & 6.38 \\
Tetraethylammonium bromide & 1.18 \\
Isobutyl (3-(methylthio)propyl) carbonate & 2.11 \\
Benzaldehyde & 2.25 \\
Heptane, 2,2,4,6,6-pentamethyl & 2.94 \\
Fenchone & 0.26 \\
2,4-heptadienal & 2.90 \\
4-Pentenoic acid 3-hydroxy- ethyl ester & 1.23 \\
Acetic acid, hexyl ester & 0.54 \\
Benzylamine & 0.30 \\
Cymene & 0.70 \\
D-limonene & 6.59 \\
Linalool & 0.70 \\
Camphor & 0.07 \\
\hline
\end{tabular}

\section{DISCUSSION}

Either cultivated or wild, fig fruits or the trees have been used as one of the main ingredients of traditional medicine. In the present study, we investigated some phytochemical and physicochemical properties of fig seeds and their cold pressed oil, in a way different from the other studies. The seeds' oil content, protein, trace elements, ash and ash insoluble in hydrochloric acid have been determined. Also cold pressed oil has been analysed for fatty acids methyl esters, antioxidant capacity, volatile oil content , tocopherol, total phenol, sterols, free fatty acids, peroxide value, 
refractive index and p-anisidine. In this study phytochemical properties of Ficus carica seed and its oil are evaluated extensively. Comparing the oil yield of cold pressed fig seed with other studies showed similarities. Joseph and $\mathrm{Raj}^{7}$ described the dried seeds' fixed oil content as $30 \%$, Hssaini et al. reported the oil content of four different fig seeds cultivars from Morocco changing between 21.54-29.65 $\% .{ }^{15}$ Different fig seeds from Turkey resulted with lower or similar oil yields as $14.08,18$, and $23.67 \%$ for different cultivars. ${ }^{34-36}$ Our results are comparable with the other studies about figs and also were comparable with the studies about the other fruit seeds oil content such as blackcurrant (16.5-30.4\%), gooseberry (15.6-35.2\%), lime (22.1-31.9\%), passion fruit (18.5-30.4\%), pear (16.3-31.7\%), redcurrant $(22.8-30.1 \%)^{37}$, pumpkin (27.83-45.4\%), honeydew (25.0$32.3 \%$ ), water melon $(22.1-36.65 \%){ }^{38}$ The amount of oil and oil components of the seeds may differ with various factors such as variety, climate, origin, ripeness level, size, pollination factor and extraction processes. ${ }^{15,39}$ Since the fig seeds samples show an important oil yield, the seeds maybe evaluated as a good source of oil and be commercialized as a value added product.

In our study protein content of the fig seeds was found at $14.65 \%$. Vinson ${ }^{40}$ reported the protein content of $100 \mathrm{gr}$ dried figs as $3.14 \mathrm{~g}$. For fresh figs these values were 0.72$0.74 .^{41}$ In another study, protein content was $0.64-0.72 \mathrm{~g}$ for fig peel, 7.88-8.11 g for pulp. ${ }^{42}$ Nakilcioglu Tas ${ }^{36}$ determined the protein content of the fig seeds between 14.74-15.07\%. Comparing the protein content with other seeds, rambutan seed protein content (12.4\%) was the most similar seed with fig seed. ${ }^{38}$

The results of ash content and ash insoluble in hydrochloric acid were $2.6 \mathrm{~g}$ and $0.2 \mathrm{~g}$, respectively in the current study. Other studies reported the ash content for peel as 3.80-4.73 g and for pulp 3.23-3.53 g, 2.99\% for fig seed, ${ }^{36,42} 0.83-1.12 \%$ for fresh figs ${ }^{41}$ and similarly for mango seed at $2 \% .{ }^{38}$ Our results are similar with the fig seed samples. The reasons for the difference in the amount of ash content especially compared with the fresh figs, might be related with the jellylike meat which is not found in our dried and cleaned seed samples. Higher ash content can indicate higher amounts of minerals having constructive effects on health. ${ }^{36}$

Potassium, magnesium and calcium were the main trace elements in the dried fig seeds in this study. Vinson ${ }^{40}$ found the nutrients in $100 \mathrm{~g}$ of dried figs for calcium $133.0 \mathrm{mg}$, potassium $609 \mathrm{mg}$, sodium $12.26 \mathrm{mg}$ and also showed that dried figs almost have as much calcium (53 $\mathrm{mg})$ as oranges $(62 \mathrm{mg})$ have. Nakilcioglu $\mathrm{Tas}^{36}$ stated calcium (185.67-190.42 $\mathrm{mg} \mathrm{kg}^{-1}$ ), potassium (166.73-172.83 $\mathrm{mg} \mathrm{kg}{ }^{-1}$ ) and phosphorus (178.36-186.21 $\mathrm{mg} \mathrm{kg}^{-1}$ ) were the major minerals, while copper and manganese were the trace elements for the fig seeds. Also the United States Department of Agriculture (USDA) data stated that dried figs are richer in calcium, copper, potassium, magnesium and manganese. ${ }^{5}$ In a study it was mentioned that mango seeds are rich in terms of calcium (10.21-111.3 mg/100g), magnesium (22.34-94.8 mg/199g) and potassium (22.3$158.0 \mathrm{mg} / 100 \mathrm{~g}) .{ }^{43}$ Comparing the results of this study with other studies, the main recurring minerals in other studies are similar to our study, but the individual main minerals' amounts vary as percentages of overall content according to the different varieties of figs. Evaluating the results in terms of trace elements, fig fruits and seeds are excellent sources for a mineral-balanced diet to support the body in many ways from transmitting nerve impulses to structuring bones. ${ }^{36,44}$

\section{Fatty acid methyl esters (FAME) composition}

Polyunsaturated fatty acids (PUFA) and monounsaturated fatty acid (MUFA) ${ }^{33}$ were the most abundant components in FAME composition. Comparing this study with the other studies of dried figs, linolenic acid was found to be the most predominant fatty acid with $53.1 \%$, linoleic acid $21.1 \%$, palmitic acid $13.8 \%$, and oleic acid at $9.8 \% .{ }^{4}$ The studies with latex showed that the fatty acid composition mostly contains palmitic (21.4\%), arachidic (44.1\%), and behenic acids (13.1\%). Latex contains mostly saturated fatty acids (161.77 mg/kg), MUFA (5.89 mg/kg), PUFA (14.59 mg/kg). [1.5] Our results are compatible with two other studies about fig seed oil. These studies showed that the main saturated fatty acids were palmitic acid (3.57-7.40\% and 8.53-9.05\%) and stearic acid (2.97-3.73\% and 2.59-3.30\%). Arachidic, behenic, margaric and lignoceric acids were determined to exist in trace levels. In terms of unsaturated fatty acids, linolenic acid (37.87-41.80\% and 38.43-43.57\%), linoleic acid (31.80-37.95\% and $28.90-34.51 \%)$ and oleic acid (16.82$17.79 \%$ and $13.43-15.64 \%)$ were found with the highest values, similar to our study. MUFA value (18.42\%) of this study was higher than the other two studies, PUFA (71.54\%) was lower and TSFA (9.99\%) was within the ranges of the other two studies. ${ }^{15,36}$ The saturated fatty acid profile of this study was similar to guava and melon seeds oil ${ }^{38,45}$ and linolenic acid content of the fig seed oil might be considered to be similar to raspberry, bilberry and elderberry. ${ }^{37}$ Since the $\omega-6 / \omega-3$ rate (0.72) was lower, fig seed oil might be recommended for a healthy diet and can be evaluated as a new source for $\omega$-3 fatty acids.

Unsaturated fatty acids (89.96\%) and a lower rate of $\omega$ $6 / \omega-3$ are responsible for many important functions in the body. The studies show that linoleic and linolenic acids, which are included with polyunsaturated fatty acids, are responsible for converting the eicosanoids-hormone likesubstances to be in different physiological reactions such as the immune response and blood clotting. ${ }^{4}$ By reducing low-density lipoprotein cholesterol and blood pressure level, oleic acid also has an important supportive function with coronary heart problems. ${ }^{46}$ Even though the fatty acids ranges are different, the unsaturated and saturated fatty acids ratios were found similar with other studies.

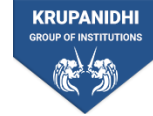


These differences can be related to different environmental conditions such as geographical difference, climate change and other factors like genetics, and plant species.

\section{Total phenolic content}

Total phenolic content of the cold pressed fig seed oil was found to be $79.5 \mathrm{mg} \mathrm{GAE} / 100 \mathrm{~g}$ in our study. Other studies' results from different cultivars of dried fig extract were 11.7, 10.1 and $14.8 \mathrm{mg}$ chlorogenic acid equivalents/g, ${ }^{47}$ from stem $539.17 \pm 3.21 \mathrm{mg} \mathrm{GAE} / 100 \mathrm{~g}$, from root $573.06 \pm$ $2.74 \mathrm{mg} \mathrm{GAE} / 100 \mathrm{~g}$, from leaves $531.76 \pm 4.90 \mathrm{mg} \mathrm{GAE} / 100$ $\mathrm{g},{ }^{48}$ from overall fresh fruit $1,090-1,110 \mathrm{mg} \mathrm{GAE} / 100$ g. ${ }^{40}$ Another study, which subjected the peel and pulp separately, found the total phenolic content for peel in the range of 4.78$5.76 \mathrm{mgGAE} / \mathrm{g}$ sample and $1.92-2.67 \mathrm{mgGAE} / \mathrm{g}$ sample ${ }^{42}$ and level of total phenolics for F. carica stem extracts was $133 \mathrm{mg}$ GAE/g. ${ }^{10}$ In a study from a Turkish region for different $F$. carica fruits, total phenolic content was analyzed for Bursa siyahi, Karabakunya, Sarilop and Sultan Selim and these were $37.29 \pm 1.558,33.55 \pm 1.559,28.25 \pm 1.446$, $25.47 \pm 0.936 \mathrm{mg}$ GAE g-1 respectively. ${ }^{49}$ A study from Turkey determined the total phenolic content of fresh and dried figs and the results were 199.52-307.64 mg GAE/100 $\mathrm{g}$ and 81.77-212.36 mg GAE/100 g respectively. ${ }^{50}$ Hssaini et al. ${ }^{15}$ reported the phenolic content of four different cultivars' seed soil between the range of 69.83 and 100.99 mg GAE/100 g and Ozyurt ${ }^{51}$ reported phenolic content of commercial fig seed oil as $654.73 \mathrm{mg}$ GAE/Loil. Our results were similar to dried fig and fig seed oil phenolic contents. As can be seen in different studies, which are conducted with different parts of figs (roots, root bark, stem wood and bark, leaves, branches, fruits, and seeds), phenolic compounds are found to be very widely different. These compounds are responsible in fruits for specific functions and sensory properties such as color and flavor. At the same time phenolic compounds are very important and popular with their health-promoting effects especially for their antioxidant, free-radical scavenging, and antiproliferation/antiprogression actions properties. ${ }^{5,40}$ Ficus species are an excellent source of phenolic compounds. ${ }^{11}$ Especially fig fruits are accepted as having higher amounts of phenolic compounds compared with tea and red wine which are two well-publicized sources for phenolics ${ }^{49}$ and some studies demonstrated that fresh figs contain lower phenolic amounts than dried figs ${ }^{47}$ while some others showed that the phenolic content of dried figs is lower than fresh figs. ${ }^{50}$

\section{Sterols}

Total sterol was found $6519.40 \mathrm{mg} \mathrm{kg}-1$ in our study with some other sterol components (Table 4). Other studies which are focused on different parts of fig fruits' sterol compositions have demonstrated different results. A study which was focused on the extract of F. carica latex com- position found betulol (327 mg/kg), lupeol $(2827 \mathrm{mg} / \mathrm{kg})$, lanosterol $(2634 \mathrm{mg} / \mathrm{kg})$, lupeol acetate $(1989 \mathrm{mg} / \mathrm{kg}), \beta$ amyrin $(1197 \mathrm{mg} / \mathrm{kg}), \beta$-sitosterol $(10567 \mathrm{mg} / \mathrm{kg})$, and $\alpha$ amyrin $(76 \mathrm{mg} / \mathrm{kg})$. Within the results, $\beta$-sitosterol $(54 \%)$ was the highest sterol compound while $\alpha$-amyrin $(0,4 \%)$ was the lowest ${ }^{5}$ In another study, which subjected San Francesco, Citrullara, and Dottato cultivars of dried F. carica, sterol composition was found to contain campesterol (0.2-1.0\%), stigmasterol (1.6-1.9\%), stigmasta-5,23-dien-3-ol (0.2-2.4\%) and $\beta$-sitosterol (1.5-10.3\%) with the highest rates. ${ }^{47}$ Jeong and Lanchance's study ${ }^{4}$ about different parts of the figs (fruit, bark, stem, pith) found four sterols as campesterol, stigmasterol, sitosterol and fucosterol. While fucosterols were analyzed only in fruits, sitosterol had the highest level in all parts of the fig. Total sterol contents of some seeds oils also show similarity to our results such as date palm kernel oil (336.1-788.4 mg $100 \mathrm{~g}^{-1}$ ), gooseberry seed oil $\left(586 \mathrm{mg} 100 \mathrm{~g}^{-1}\right)$ and grape seed oil (156-10596.2 mg 100 $\left.\mathrm{g}^{-1}\right) .{ }^{37}$ Comparing the other results with our study, the sterol composition ranges were similar with the dominance of beta-sitosterol. The sterols also have been reported in seeds, seed oils, roots, stems and branches, leaves and blossoms in different studies and the total amounts of sterols were not equal and the proportions were different in various parts of a plant or a tree. ${ }^{4}$ As the phytosterols are important for cholesterol elimination in the body, cellular processes and also participation in cellular differentiation and proliferation, ${ }^{47}$ fig seed oil can be considered as a valuable source for sterols.

\section{Tocopherol content}

F. carica seeds have been analyzed for their tocopherol content and in the results $\alpha, \beta, \gamma, \delta$-tocopherol were detected in different levels. The results were similar in order of contents with the Baygeldi et al. study but slightly different in amounts in which $\gamma$-tocopherol was 391.89 $\mathrm{mg} / 100 \mathrm{~g}, \delta$-tocopherol was $7.65 \mathrm{mg} / 100 \mathrm{~g}, \alpha$-tocopherol was $4.6 \mathrm{mg} / 100 \mathrm{~g}^{35}$ Some studies about tocopherols also have been conducted for different parts of the fig plant. The fig leaves have been found with a low level of $\alpha$-tocopherol on dried weight $(0.0570 \%){ }^{52}$ The fig fruit $\alpha$-tocopherol content was $0.34 \mathrm{mg} / 100 \mathrm{~g}$ and $\gamma$-tocopherol was 0.38 $\mathrm{mg} / 100 \mathrm{~g} .{ }^{53}$ Although fig fruits can be considered as being with a low level of tocopherols compared with the other fruits such as raspberries or peaches, fig seeds oil can be classified as a good source of tocopherol similar to with some other seeds such as blueberry $(260.6 \mathrm{mg} / \mathrm{kg})$ and marionberry $(978 \mathrm{mg} / \mathrm{kg}) .{ }^{54}$ Since the tocopherols have beneficial effects on health along with other components of oils such as phenolics, sterols and fatty acids, ${ }^{37}$ with its phytochemical structure fig seed oil can be a functional component in different food applications. ${ }^{38}$ 


\section{Antioxidant capacity}

Antioxidant capacity of fig seed oil was found at $52.54 \%$. Hssaini et al. ${ }^{15}$ evaluated the DPPH radical scavenging activity of four different fig cultivars' oil (C11A21, Bourjassotte noir, C7A14 and White Adriatic) and the results were in a range between 226.46-294.36 mg Trolox equivalent/g oil. In the study of Imran ${ }^{48}$ for F. benjamina they found the $\mathrm{DPPH}, \mathrm{IC}_{50}$ analysis results for stems at $50.10 \pm 3.23 \mu \mathrm{g}$ $\mathrm{mL}^{-1}$, for roots at $58.81 \pm 4.50 \mu \mathrm{g} \mathrm{mL}^{-1}$ and for leaves at $49.86 \pm 3.39 \mu \mathrm{g} \mathrm{mL}^{-1}$. Loizzo ${ }^{47}$ found the $\mathrm{DPPH}$ assays results for three different cultivars of the fig at 22.6, 38.2, $41.3 \mu \mathrm{gmL}^{-1}$ and for its honey at $11.6 \mu \mathrm{gmL}^{-1}$. Ersoy and others ${ }^{49}$ have studied four different $F$. carica cultivars in Turkey and found the DPPH values for the fruits as 1.20 , $1.26,1.42,1.49 \mathrm{mg}$ sample $\mathrm{mg}^{-1}$. The study with the coproducts of fig found the DPPH (for $100 \mathrm{mg} / \mathrm{mL}$ ) for peel between $57.56-87.35 \%$ and for the pulp between 28.97 $46.03 \% .{ }^{42}$ Following the results above, F. carica seed oil showed similar antioxidant activity with elderberry seeds. ${ }^{55}$ The DPPH radical scavenging assay is commonly used on free radicals to determine the scavenging potential of an antioxidant. The studies generally employed this analysis for different parts of figs but not for oil. Comparing with other results, which are shown, the antioxidant capacity of fig and its cold pressed oil can be considered to be a good antioxidant with its capacity. Since the antioxidants are accepted to decrease the risks of chronic diseases, a fig seed oil rich diet with natural antioxidants might be a proper choice for preventing oxidative damages and degenerative diseases. ${ }^{15}$

\section{Volatile oils}

Ninety-four different components are determined in F. carica seeds oil in this study (Table 5). The other studies isolated different volatile compounds for fig fruits (pulps and peels) such as "aldehydes: 2-methylbutanal, 3-methyl-butanal, hexanal, heptanal, (E)-2-pentanal, nonanal, and octanal, alcohols: 3-methylbutanol, 1-penten3-ol, (E)-2-nonenol, benzyl alcohol, and phenylethyl alcohol, ketone: 6-methyl-5-hepten-2-one, esters: ethyl salicylate, methyl salicylate, and methyl hexanoate, monoterpenes: $\alpha$-pinene, limonene, $\beta$-pinene, menthol, eucalyptol, linalool, sesquiterpenes: copaene, $\alpha$-cubenene, $\tau$-muurolene, $\beta$-caryophyllene, germacrene $\mathrm{D}$, and $\tau$ cadinene, norisoprenoid: $\beta$-cyclocitral, and miscellaneous compounds: eugenol" ${ }^{1,3,47}$ The leaves of $F$. carica have different volatile compounds which are classified as follows: "Aldehydes: methylbutanal, (E)-2-pentanal, hexanal, and 2-methylbutanal, (E)-2-hexanal, alcohols: 3-methyl1-butanol, 1-penten-3-ol, heptanol, 2-methylbutanol, (E)-2-nonen-1-ol, benzyl alcohol, and phenylethyl alcohol, ketone: 3-pentanone, esters: methyl butanoate, methyl hexanoate, hexyl acetate, ethyl benzoate, and methyl salicylate, sesquiterpenes: $\alpha$-guaiene, $\alpha$-cubenene, copaene, $\alpha$-ylangene, $\beta$-elemene, $\alpha$-gurjunene, $\beta$-bourbonene, $\beta$-cubebene, $\quad \beta \alpha$-caryophyllene, $\quad \alpha$-caryophyllene, aromadendrene, $\tau$-cadinene, $\tau$-muurolene, germacrene $\mathrm{D}$, $\alpha$-muurolene, and (+)-ledene, monoterpenes: limonene and menthol, norisoprenoid: $\beta$-cyclocitral, and miscellaneous compounds: psoralen". ${ }^{5}$ Each study shows different volatile compounds for different parts of figs and these studies generally focused on leaves and fruits. Considering the analyses employed for fruits, the results that we found in our study show similar and also some different compounds at the same time.

\section{Free fatty acid, peroxide value, refractive index and p-anisidine}

Physicochemical properties of fig seed oil were within the acceptance levels for edible oils in the current study. Comparing with other cold pressed seed oils, peroxide value was lower than cherry seed oil $\left(18.80 \mathrm{mEqO}_{2} / \mathrm{kg}_{\text {oil }}\right)$, pomegranate seed oil $\left(9.20 \mathrm{mEqO}_{2} / \mathrm{kg}\right.$ oil), apricot seed oil $\left(25 \mathrm{mEqO}_{2} / \mathrm{kg}\right.$ oil $)$ and coffee bean oil $\left(26.34 \mathrm{mEqO}_{2} / \mathrm{kg}\right.$ oil $)$. Free fatty acid value of fig seed oil was also lower than the cold pressed oils mentioned above. ${ }^{51}$ The refractive index was very similar with other fruit seed oils. ${ }^{56,57}$

\section{CONCLUSION}

Ficus spp. has been known as a food and therapeutic remedy since a very early time in history. Ancient sources and modern texts, mention about the various usages of fig plants. Both the seed and the oil were found to be very rich in healthy phytochemicals such as volatile oil, phenolic components; fatty acids, other chemicals possessing antioxidant activity; tocopherols and minerals of high nutritional value. Therefore, its consumption can be encouraged in a daily diet and also in supplements by health professionals for special treatments such as macular degeneration or natural anti-aging remedies.

\section{CONFLICT OF INTEREST STATEMENT}

The authors have no affiliations with or involvement in any organization or entity with any financial or non financial interest in the subject matter or materials discussed in this manuscript.

\section{REFERENCES}

1. Barolo MI, Mostacero NR, López SN. Ficus carica L. (Moraceae): An ancient source of food and health. Food Chemistry. 2014;164:119-127. doi:10.1016/j.foodchem.2014.04.112.

2. Abbasi AM, Khan MA, Khan N, Shah MH. Ethnobotanical survey of medicinally important wild edible fruits species used by tribal communities of Lesser Himalayas-Pakistan. Journal of Ethnopharmacology. 2013;148(2):528-536. doi:10.1016/j.jep.2013.04.050.

3. Mawa S, Husain K, Jantan I. Ficus caricaL. (Moraceae): Phytochemistry, Traditional Uses and Biological Activities. Evidence-Based Complementary and Alternative Medicine. 2013;2013(974256):1-8. doi:10.1155/2013/974256. 
4. Jeong WS, Lachance PA. Phytosterols and Fatty Acids in Fig (Ficus carica, var. Mission) Fruit and Tree Components. Journal of Food Science. 2001;66(2):278-281. doi:10.1111/j.1365-2621.2001.tb11332.x.

5. Badgujar SB, Patel VV, Bandivdekar AH, Mahajan RT. Traditional uses, phytochemistry and pharmacology ofFicus carica: A review. Pharmaceutical Biology. 2014;52(11):1487-1503. doi:10.3109/13880209.2014.892515.

6. Guarrera PM. Traditional phytotherapy in Central Italy (Marche, Abruzzo, and Latium). Fitoterapia. 2005;76(1):1-25. doi:10.1016/j.fitote.2004.09.006.

7. Joseph B, Raj SJ. Pharmacognostic and phytochemical properties of Ficus carica Linn -An overview. International Journal of PharmTech Research. 2011;3(1):8-12.

8. Stepek G, Behnke JM, Buttle DJ, Duce IR. Natural plant cysteine proteinases as anthelmintics? Trends in Parasitology. 2004;20(7):322327. doi:10.1016/j.pt.2004.05.003.

9. Mujeeb M, Khan SA, Aeri V, Ali B. Hepatoprotective Activity of the Ethanolic Extract of Ficus caricaLinn. LeavesinCarbon TetrachlorideInduced Hepatotoxicityin Rats. Iranian journal of pharmaceutical research : IJPR. 2011;10(2):301-306.

10. Saoudi M, Feki AE. Protective Role ofFicus caricaStem Extract against Hepatic Oxidative Damage Induced by Methanol in Male Wistar Rats. Evidence-Based Complementary and Alternative Medicine. 2012;2012:1-8. doi:10.1155/2012/150458.

11. Salem M, Salem A, Camacho LM, Ali HM. Antimicrobial activities and phytochemical composition of extracts of Ficus species : An over view. African Journal of Microbiology Research. 2013;7(33):4207-4226.

12. Joerin L, Kauschka M, Bonnländer B, Pischel I, Benedek B, Butterweck V. Ficus carica Leaf Extract Modulates the Lipid Profile of Rats Fed with a High-Fat Diet through an Increase of HDL-C. Phytotherapy Research. 2014:28(2):261-267. doi:10.1002/ptr.4994.

13. Bhanushali M, Joshi Y, Makhija D. Central nervous system activity of an aqueous acetonic extract of Ficus carica L. in mice. Journal of Ayurveda and Integrative Medicine. 2014;5(2):89. doi:10.4103/09759476.131734.

14. Abbasi AM, Khan MA, Shah MH, Shah MM, Pervez A, Ahmad M. Ethnobotanical appraisal and cultural values of medicinally important wild edible vegetables of Lesser Himalayas-Pakistan. Journal of Ethnobiology and Ethnomedicine. 2013;9(1):1-13. doi:10.1186/17464269-9-66.

15. Hssaini L, Hanine H, Charafi J, Razouk R, Elantari A, Ennahli S, et al. First report on fatty acids composition, total phenolics and antioxidant activity in seeds oil of four fig cultivars (Ficus carica L.) grown in Morocco. OCL. 2020;27(8):1-10. doi:10.1051/ocl/2020003.

16. Argon ZU, Gokyer A. Determination of Physicochemical Properties of Nigella sativa Seed Oil from Balıkesir Region. Turkey Chemical and Process Engineering Research. 2016;41:43-46.

17. Topkafa M. Evaluation of chemical properties of cold pressed onion, okra, rosehip, safflower and carrot seed oils: triglyceride, fatty acid and tocol compositions. Analytical Methods. 2016;8(21):4220-4225. doi:10.1039/c6ay00709k.

18. Gharibzahedi SMT, Mousavi SM, Hamedi M, Rezaei K, Khodaiyan F. Evaluation of physicochemical properties and antioxidant activities of Persian walnut oil obtained by several extraction methods. Industrial Crops and Products. 2013;45:133-140. doi:10.1016/j.indcrop.2012.11.040.

19. El-Shurafa MY, Ahmed HS, Abou-Naji SE. Organic and inorganic constituents of date palm pit (seed). Date Palm Journal. 1982;1(2):275284.

20. EP 8.0. 2.4.16. Total Ash. In: The European Pharmacopoeia. Strasbourg, France: European Directorate for the Quality of Medicines \& HealthCare (EDQM) Council of Europe. 2013.

21. EP 8.0. 2.8.1.Ash Insoluble in Hydrochloric Acid. In: The European Pharmacopoeia. Strasbourg, France: European Directorate for the Quality of Medicines \& HealthCare (EDQM) Council of Europe. 2013.

22. US EPA. Method 3051A Microwave Assisted Acid Digestion of Sediments, Sludges, Soils, and Oils, Revision 1. Washington, DC: United States Environmental Protection Agency. Washington, DC. 2007.
23. IOC. Determination of fatty acid methyl ester ethoxylates by gas chromatography. Vol. COI/T.20, International Olive Council. Madrid: International Olive Council. 2017. Available from: http://www. internationaloliveoil.org.

24. EP 8.0. 2.4.23. Sterols in Fatty Oils. In: The European Pharmacopoeia Strasbourg, France: European Directorate for the Quality of Medicines \& HealthCare (EDQM) Council of Europe. 2013.

25. Ferhat R, Lekbir A, Ouadah H, Kahoul MA, Khlalfa L, Larouni S. Effect of extraction solvent on total phenolic content, total flavonoid content, and antioxidant activities of Algerian pomace olive oil. International Food Research Journal. 2017;24(6):2295-2303.

26. Celenk VU, Gumus ZP, Argon ZU, Buyukhelvacigil M, Karasulu E. Analysis of Chemical Compositions of 15 Different Cold-Pressed Oils Produced in Turkey: A Case Study of Tocopherol Analysis. Journal of the Turkish Chemical Society, Section A: Chemistry. 2017;5(1):1-20. doi:10.18596/jotcsa.335012.

27. Filho LCC, Martinazzo AP, de Souza Teodoro CE, Vivès L. Microbiological quality and essential oil of parsley ( Petroselinum crispum ) submitted to the hygienizing and drying process. Industrial Crops and Products. 2018;114:180-184. doi:10.1016/j.indcrop.2018.01.063.

28. EP 8.0. 2.5.1. Acid Value. In: The European Pharmacopoeia. Strasbourg, France: European Directorate for the Quality of Medicines \& HealthCare (EDQM) Council of Europe. 2013.

29. EP 8.0. 2.5.5. Peroxide Value. In: The European Pharmacopoeia. Strasbourg, France: European Directorate for the Quality of Medicines \& HealthCare (EDQM) Council of Europe. 2013.

30. EP 8.0. 2.2.6. Refractive Index. In: The European Pharmacopoeia. Strasbourg, France: European Directorate for the Quality of Medicines \& HealthCare (EDQM) Council of Europe. 2013.

31. AOCS. Cd 18-90 p-Anisidine Value. In: Official Methods and Recommended Practices of the American Oil Chemists' Society. Champaign: AOCS Press. AOCS Press. 2004.

32. Tadesse N, Reta N, Beyero N. Level of Saturation and Anti-Oxidant Value of Heat and Spice Treated Animal Butter. Food and Public Health. 2017;7. Available from: http://article.sapub.org/10.5923.j.fph. 20170704.02.html.

33. Ustun-Argon Z, Gokyer A, Koparal B. Physicochemical Evaluation of Fig and Mulberry Seed's Cold Pressed Oils. The Fourth International Mediterranean Symposium on Medicinal and Aromatic Plants-(MESMAP)-Abstract Book. 2018;p. 69.

34. Ergün Z, Bozkurt T. Determination Of Fatty Acid Composition And Antioxidant Activity Of Fig Seed Oil. International Journal of Agricultural and Natural Sciences. 2020;13(2):101-107.

35. Baygeldi N, Küçükerdönmez Ö, Akder RN, Çağındı Ö. Medicinal and nutritional analysis of fig ( ficus carica) seed oil ; a new gamma tocopherol and omega-3 source. Progress in Nutrition. 2021;23(2):16.

36. Tas EN. Biochemical characterization of fig (Ficus carica L.) seeds. Tarim Bilimleri Dergisi. 2019;25:232-239.

37. Alves E, Simoes A, Domingues MR. Fruit seeds and their oils as promising sources of value-added lipids from agro-industrial byproducts: oil content, lipid composition, lipid analysis, biological activity and potential biotechnological applications. Critical Reviews in Food Science and Nutrition. 2021;61(8):1305-1339. doi:10.1080/10408398.2020.1757617.

38. Raihana ARN, Marikkar JMN, Amin I, Shuhaimi M. A Review on Food Values of Selected Tropical Fruits' Seeds. International Journal of Food Properties. 2015;18(11):2380-2392. doi:10.1080/10942912.2014.980946.

39. Argon ZU, Celenk VU, Gumus ZP. Cold pressed grape (Vitis vinifera) seed oil. In: MF R, editor. Cold Pressed Oils. Elsevier. 2020;p. 39-52.

40. Vinson JA. The functional food properties of figs. Cereal Foods World. 1999;44(2):82-89.

41. Kim SS, Lee CH, Oh SY, D-H C. Chemical components in the two cultivars of Korean figs(Ficus carical L.).pdf. The Korean Society for. Applied Biological Chemisty. 1992;35(1):51-55.

42. Viuda-Martos M, Barber X, Pérez-Álvarez JA, Fernández-López J. Assessment of chemical, physico-chemical, techno-functional and antioxidant properties of fig (Ficus carica L.) powder co- 
products. Industrial Crops and Products. 2015;69:472-479. doi:10.1016/j.indcrop.2015.03.005.

43. Kittiphoom S. Utilization of Mango seed. International Food Research Journal. 2012;19(4):1325-1360.

44. Solomon A, Golubowicz S, Yablowicz Z, Grossman S, Bergman M, Gottlieb HE, et al. Antioxidant Activities and Anthocyanin Content of Fresh Fruits of Common Fig (Ficus carica L.). Journal of Agricultural and Food Chemistry. 2006;54(20):7717-7723. doi:10.1021/jf060497h.

45. Silva MA, Albuquerque TG, Alves RC, Oliveira MBPP, Costa HS. Melon seeds oil, fruit seeds oil and vegetable oils: a comparison study. Annals of Medicine. 2019;51(sup1):166-166. doi:10.1080/07853890.2018.1561973.

46. Waterman E, Lockwood B. Active Components and Clinical Applications of Olive Oil. Alternative Medicine Review. 2007;12(4):331-373.

47. Loizzo MR, Bonesi M, Pugliese A, Menichini F, Tundis R. Chemical composition and bioactivity of dried fruits and honey of Ficus carica cultivars Dottato, San Francesco and Citrullara. Journal of the Science of Food and Agriculture. 2014;94(11):2179-2186. doi:10.1002/jsfa.6533.

48. Imran M, Rasool N, Rizwan K, Zubair M, Riaz M, Zia-Ul-Haq M, et al. Chemical composition and Biological studies of Ficus benjamina. Chemistry Central Journal. 2014;8(1):12-22. doi:10.1186/1752-153x8-12.

49. Ersoy N, Gozlekci S, Gok V, Yilmaz S. Fig (Ficus caricaL.) fruit: some physical and chemical properties. Acta Horticulturae. 2017;1173(1173):329-334. doi:10.17660/actahortic.2017.1173.57.

50. Bakırcı GT, Hışıl Y. Fast and simple extraction of pesticide residues in selected fruits and vegetables using tetrafluoroethane and toluene followed by ultrahigh-performance liquid chromatography/tandem mass spectrometry. Food Chemistry. 2012;135(3):1901-1913. doi:10.1016/j.foodchem.2012.06.051.

51. Ozyurt VH. Comparison of the Quality Properties of Some Commercial Cold pressed Seed Oils. Journal of The Turkish Chemical Society-Section A. 2019;6(2):149-156.

52. Konyalio囚lu S, Sa囚lam H, Kivçak B. $\alpha$-tocopherol, flavonoid, and phenol contents and antioxidant activity of Ficus carica leaves. Pharmaceutical Biology. 2005;43(8):683-689.

53. Chun J, Lee J, Ye L, Exler J, Eitenmiller RR. Tocopherol and tocotrienol contents of raw and processed fruits and vegetables in the United States diet. Journal of Food Composition and Analysis. 2006;19(2-3):196-204. doi:10.1016/j.jfca.2005.08.001.

54. Parry JW. Value-adding factors in cold-pressed edible seed oils and flours. University of Maryland. 2006.

55. Fidelis $M$, Moura D, Kabbas $T$, Pap N, Mattila P, Mäkinen $S$, et al. Fruit Seeds as Sources of Bioactive Compounds: Sustainable Production of High Value-Added Ingredients from ByProducts within Circular Economy. Molecules. 2019;24(21):1-54. doi:10.3390/molecules 24213854

56. Atta MB. Some characteristics of nigella (Nigella sativa L.) seed cultivated in Egypt and its lipid profile. Food Chemistry. 2003;83(1):63-68. doi:10.1016/s0308-8146(03)00038-4.

57. Cheikh-Rouhou S, Besbes S, Hentati B, Blecker C, Deroanne C, Attia H. Nigella sativa L.: Chemical composition and physicochemical characteristics of lipid fraction. Food Chemistry. 2007;101(2):673-681. doi:10.1016/j.foodchem.2006.02.022. 